\title{
Study of Concrete Involving Use of Waste Glass as Partial Replacement of Fine Aggregates
}

\author{
M. Iqbal Malik, Muzafar Bashir, Sajad Ahmad, Tabish Tariq, Umar Chowdhary \\ Students, B-Tech Civil Engineering, IUST, Awantipora, J\&k, INDIA.
}

\begin{abstract}
Concrete industry is one of the largest consumers of natural resources due to which sustainability of concrete industry is under threat. The environmental and economic concern is the biggest challenge concrete industry is facing. In this paper, the issues of environmental and economic concern are addressed by the use of waste glass as partial replacement of fine aggregates in concrete. Fine aggregates were replaced by waste glass powder as $10 \%, 20 \%, 30 \%$ and $40 \%$ by weight for M-25 mix. The concrete specimens were tested for compressive strength, splitting tensile strength, durability (water absorption) and density at 28 days of age and the results obtained were compared with those of normal concrete. The results concluded the permissibility of using waste glass powder as partial replacement of fine aggregates up to $30 \%$ by weight for particle size of range $0-1.18 \mathrm{~mm}$.
\end{abstract}

Keywords: - Compressive strength, Durability, split tensile strength, Waste Glass Concrete, Workability.

\section{INTRODUCTION}

In order to make concrete industry sustainable, the use of waste materials in place of natural resources is one of the best approaches. An enormous quantity of waste glass is generated all around the world. In India, $0.7 \%$ of total urban waste generated comprises of glass [1]. UK produces over three million tons of waste glass annually [2] Waste glass is crushed into specified sizes for use as aggregate in various applications such as water filtration, grit plastering, sand cover for sport turf and sand replacement in concrete [3].

Concrete is most widely used man made construction material and its demand is increasing day by day. The use of river sand as fine aggregate leads to exploitation of natural resources, lowering of water table, sinking of bridge piers and erosion of river bed. If fine aggregate is replaced by waste glass by specific percentage and in specific size range, it will decrease fine aggregate content and thereby reducing the ill effects of river dredging and thus making concrete manufacturing industry sustainable. The amount of waste glass produced has gradually increased over the recent years due to an ever growing use of glass products. Most waste glass has and is being dumped into landfill sites. The land filling of waste glass is undesirable because waste glass is non biodegradable which makes them environmentally less friendly. Utilization of this waste is the need of the hour. There is huge potential for using waste glass in the concrete construction sector. When waste glasses are reused in making concrete products, the production cost of concrete will go down [4]. This move will serve two purposes; first, it will be environment friendly; second, it will utilize waste in place of precious and relatively costlier natural resources.

The using of waste glass as fine aggregate in concrete creates a problem in concrete due to ASR (Alkali Silica Reaction). The reaction between alkalis in Portland cement and silica in aggregates forms silica gel. This gel is prone to swelling. It absorbs water and the volume of the gel increases. Under confinement by cement matrix and aggregate, the swelling of the ASR gel generates hydrostatic pressure. If the reaction continues and internal pressure exceeds the tensile strength of the matrix, cracks will form around the reactive aggregate particles [5]. Ground waste glass was used as fine aggregate in concrete and no reaction was detected with fine particle size, thus indicating the feasibility of the waste glass reuse as fine aggregate in concrete. In addition, waste glass seemed to positively contribute to the mortar micro-structural properties resulting in an evident improvement of its mechanical performance [6]. Larger the particle size of waste glass more is the chance of ASR occurrence. Shayan and Xu reported fine glass powder for incorporation into concrete up to $30 \%$ as a pozzolanic material suppressed the ASR [7]. Hence the size of waste glass used was in the range $0-1.18 \mathrm{~mm}$.

In this research, fine aggregates were partially replaced by waste glass as $10 \%, 20 \%, 30 \%$ and $40 \%$ by weight. Concrete specimens were tested for compressive strength, splitting tensile strength, durability (water absorption) and light weight nature for different waste glass percentages. The results obtained were compared with results of normal M-25 concrete mix and it was found that maximum increase in compressive strength occurred for the concrete mix containing $20 \%$ waste glass as fine aggregate. With increase in waste glass content, water absorption decreased indicating increase in durability. Density of concrete decreased with increase in waste glass content thus making concrete light weight in nature. 
This paper summarized the behavior of concrete involving replacement of fine aggregates by waste glass as $10 \%, 20 \%, 30 \%$ and $40 \%$ by weight which may help to reduce the disposal problems of waste glass and enhance properties of concrete.

\subsection{Cement and Aggregates}

\section{MATERIALS USED}

Khyber ordinary Portland cement of 43 grade confining to IS 8112 [8] was used throughout the work. Fine aggregates used throughout the work comprised of clean river sand with maximum size of $4.75 \mathrm{~mm}$ conforming to zone II as per IS383-1970 [9] with specific gravity of 2.6. Coarse aggregates used consisted of machine crushed stone angular in shape passing through $20 \mathrm{~mm}$ IS sieve and retained on $4.75 \mathrm{~mm}$ IS sieve with specific gravity of 2.7 .

\subsection{Glass Powder}

Waste glass was collected from Trilok Glass House, Srinagar, J\&K, consisting of waste window glass (Soda Lime glass). It was pulverized in Los Angeles abrasion apparatus and then sieved through $1.18 \mathrm{~mm}$ IS sieve. The specific gravity of waste glass was found to be 2.42. Chemical composition of glass is presented in TABLE 1. Fig.1 shows sieved glass powder and Fig.2 shows manual mixing of glass powder with sand.

\subsection{Mix Proportion}

\section{EXPERIMENTAL INVESTIGATION}

The concrete mix design was proposed by using IS 10262 [10]. The grade of concrete used was M-25 with water to cement ratio of 0.45 . The mixture proportions used in laboratory for experimentation are shown in TABLE 2.

\subsection{Test on Fresh Concrete}

3.2.1. Slump Test The workability of all concrete mixtures was determined through slump test utilizing a metallic slump mould. The difference in level between the height of mould and that of highest point of the subsided concrete was measured and reported as slump. The slump tests were performed according to IS 11991959 [11].

\subsection{Tests on hardened concrete}

From each concrete mixture, cubes of size $150 \mathrm{~mm}$ x $150 \mathrm{~mm}$ x $150 \mathrm{~mm}$ and $150 \mathrm{~mm}$ x $300 \mathrm{~mm}$ cylinders have been casted for the determination of compressive strength and splitting tensile strength respectively. The concrete specimens were cured under normal conditions as per IS 516-1959 [12] and were tested at 7 days and 28days for determining compressive strength as per IS 516-1959 [13] and splitting tensile strength as per IS 5816-1999 [14].

\subsection{Water absorption test}

The average dry weight of cube specimens after removing from moulds was measured and the average weight of cube specimens after submerging in water for curing was measured at 28 days of age. The percentage of water absorption was measured for each concrete specimen and it gave indirect measure of durability.

\subsection{Light weight character}

The average dry weight of concrete cube specimens containing $10 \%, 20 \%, 30 \%$ and $40 \%$ waste glass powder in place of fine aggregates was compared with average dry weight of normal M-25 concrete cube specimens and the percentage decrease in dry weight was measured.

\section{RESULTS AND DISCUSSION}

\subsection{Fresh concrete}

The slump values of all the mixtures are represented in TABLE 2. The slump increased with the increase in waste glass content. Waste glass particles absorbed less water as compared to sand and thus improving the workability of concrete mix. Slump was maximum for the concrete mixture containing $40 \%$ waste glass in place of fine aggregates. The variation of slump with waste glass content is depicted in Fig. 3 .

TABLE 1 - Chemical Composition of Glass

\begin{tabular}{|l|l|l|l|l|l|l|}
\hline Oxides & $\mathrm{SiO}_{2}$ & $\mathrm{Al}_{2} \mathrm{O}_{3}$ & $\mathrm{Fe}_{2} \mathrm{O}_{3}$ & $\mathrm{MgO}$ & $\mathrm{Na}_{2} \mathrm{O}$ & $\mathrm{K}_{2} \mathrm{O}$ \\
\hline Percentage & 70.4 & 1.9 & 1.2 & 10.3 & 14.0 & 0.4 \\
\hline
\end{tabular}




\subsection{Hardened concrete}

The compressive strength tests and splitting tensile strength tests are presented in TABLE 3. Compressive strength tests and splitting tensile strength tests were carried out at 7 and 28 days. An increase in compressive strength was observed up to $30 \%$ replacement of fine aggregates by waste glass and there after decreasing. The maximum compressive strength measured was $25 \%$ more than that of reference mix at 28 days corresponding to concrete mix containing $20 \%$ waste glass in place of fine aggregates. Compressive strength for concrete mix with $40 \%$ waste glass content was found to be less than that of reference mix. Splitting tensile strength decreased with increasing waste glass content. Fig. 4 and 5 present compressive strength of all mixtures at 7 and 28 days respectively. Fig. 6 and 7 present splitting tensile strength of all mixtures at 7 and 28 days respectively.

\subsection{Water absorption}

Water absorption test was carried out for all mixtures and percentage water absorption was measured. The percentage water absorption decreased with increase in waste glass content. The lowest value of water absorption was found for concrete mix with $40 \%$ waste glass content. TABLE 4 depicts the percentage water absorption for all mixtures.

\subsection{Light weight character}

Average dry weight of cube specimens of each mixture as compared to reference mix was studied and it was observed that density decreased with increase in waste glass content. The results showed $5 \%$ reduction in dry weight of concrete cube specimens for concrete mix with $40 \%$ waste glass content as compared to reference mix. Thus, waste glass concrete is light weight in nature. TABLE 5 depicts the value of dry density and percentage change in dry weight with respect to reference mix.

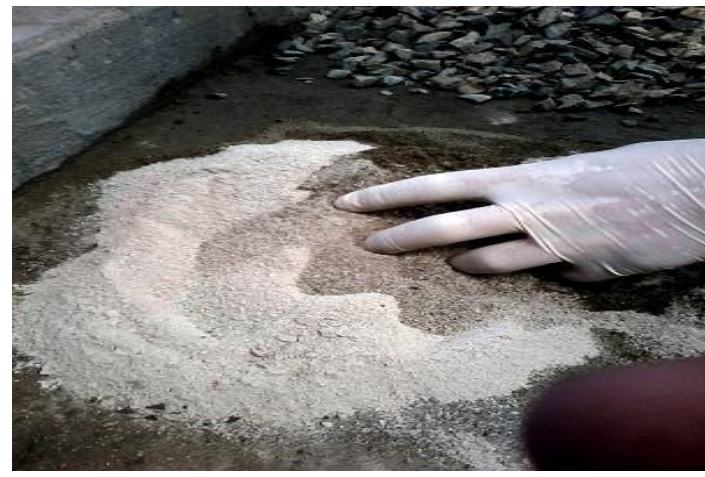

Fig.1 - Sieved glass powder

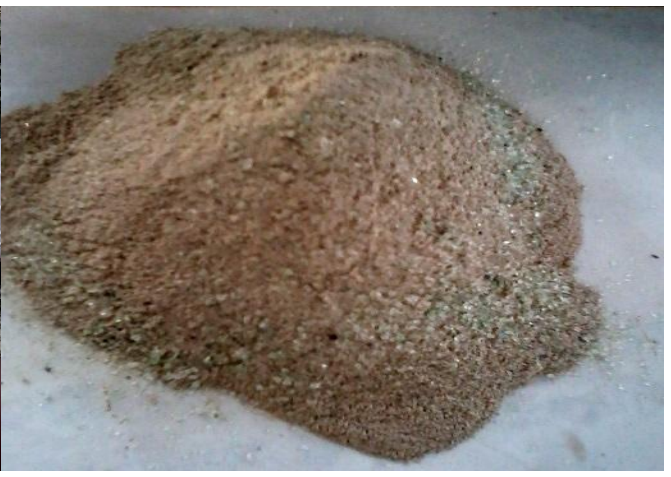

Fig.2 - Glass powder being mixed with sand

TABLE 2-Mixture Proportion

\begin{tabular}{|l|l|l|l|l|l|l|l|}
\hline $\begin{array}{l}\text { Waste Glass } \\
\%\end{array}$ & w/c ratio & $\begin{array}{l}\text { Water } \\
\left.(\mathrm{Kg} \mathrm{m})^{3}\right)\end{array}$ & $\begin{array}{l}\text { Cement } \\
\left.(\mathrm{Kg} \mathrm{m})^{3}\right)\end{array}$ & $\begin{array}{l}\text { Fine Aggregate } \\
(\mathrm{Kg} \mathrm{m})^{3}\end{array}$ & $\begin{array}{l}\text { Waste Glass } \\
\left.(\mathrm{Kg} \mathrm{m})^{3}\right)\end{array}$ & $\begin{array}{l}\text { Coarse Aggregate } \\
(\mathrm{Kg} \mathrm{m})^{3}\end{array}$ & $\begin{array}{l}\text { Slump } \\
(\mathrm{mm})\end{array}$ \\
\hline 0 & 0.45 & 191.6 & 425.8 & 543.5 & 0.00 & 1199.36 & 25 \\
\hline 10 & 0.45 & 191.6 & 425.8 & 489.15 & 54.35 & 1199.36 & 29 \\
\hline 20 & 0.45 & 191.6 & 425.8 & 434.80 & 108.70 & 1199.36 & 34 \\
\hline 30 & 0.45 & 191.6 & 425.8 & 380.45 & 163.05 & 1199.36 & 40 \\
\hline 40 & 0.45 & 191.6 & 425.8 & 326.10 & 217.40 & 1199.36 & 50 \\
\hline
\end{tabular}

TABLE 3 - Compressive strength and splitting tensile strength test results

\begin{tabular}{|c|c|c|c|c|}
\hline \multirow{2}{*}{$\begin{array}{l}\text { Waste } \\
\text { Glass in \% }\end{array}$} & \multicolumn{2}{|c|}{ Cube compressive Strength (N/mm } & \multicolumn{2}{|c|}{ Cylinder splitting tensile strength $\left(\mathrm{Nmm}{ }^{2}\right)$} \\
\hline & 7 days & 28 days & 7 days & 28 days \\
\hline 0 & 21.48 & 28.07 & 2.12 & 2.55 \\
\hline 10 & 24.29 & 33.69 & 2.08 & 2.48 \\
\hline 20 & 24.73 & 35.11 & 2.02 & 2.30 \\
\hline 30 & 22.37 & 30.82 & 1.80 & 2.16 \\
\hline 40 & 18.07 & 25.69 & 1.63 & 1.91 \\
\hline
\end{tabular}




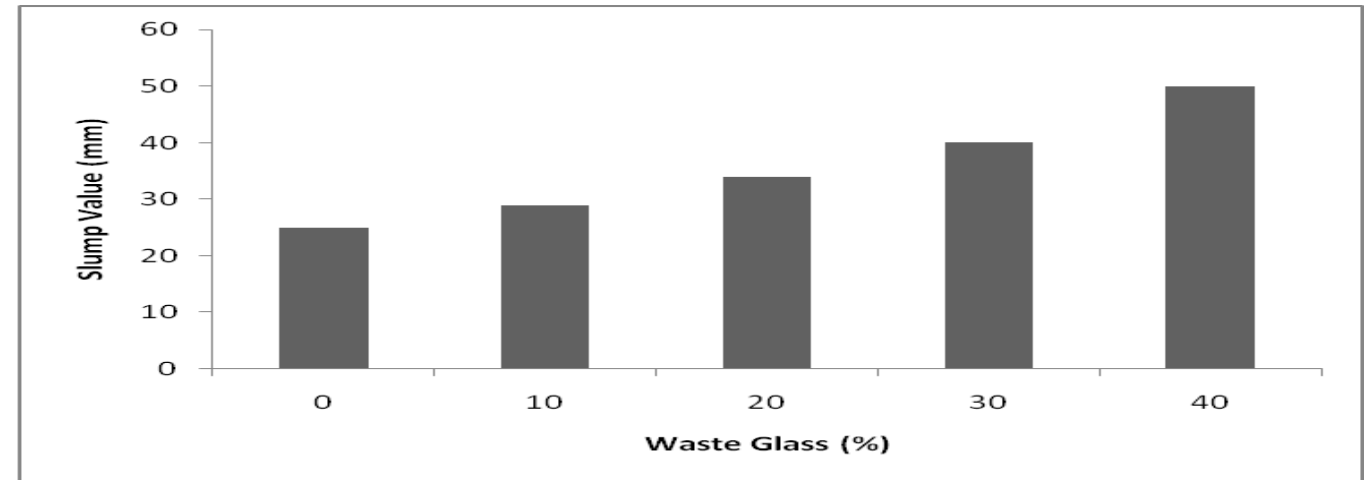

Fig.3 - Variation of slump with waste glass content.

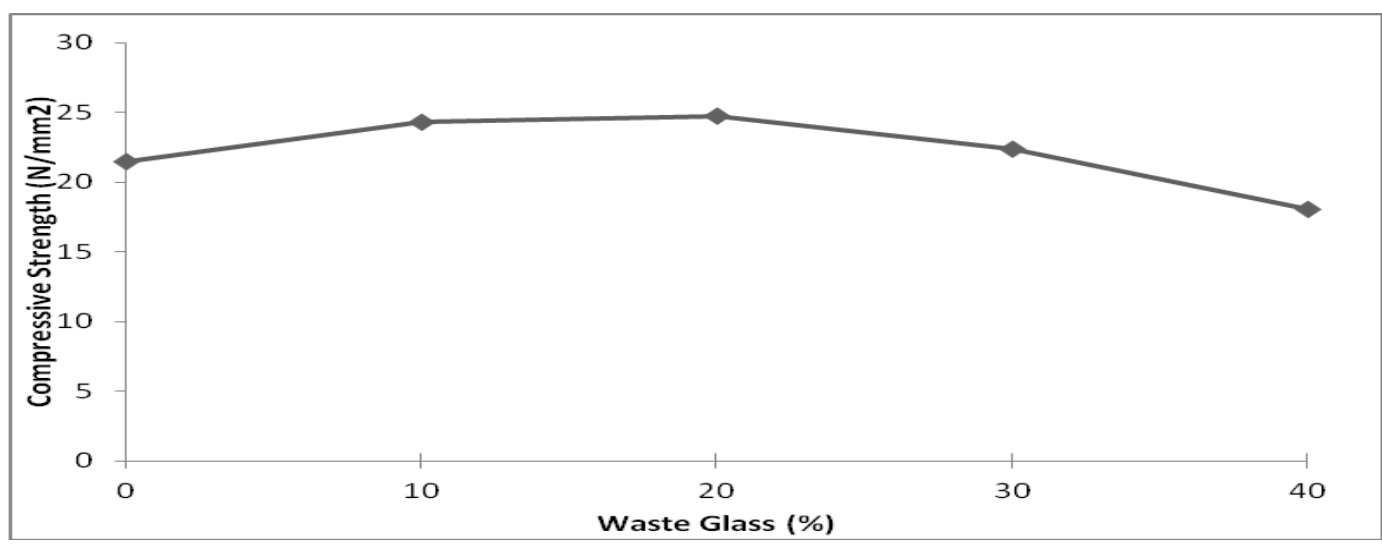

Fig.4 - Compressive Strength of Cubes at 7 Days

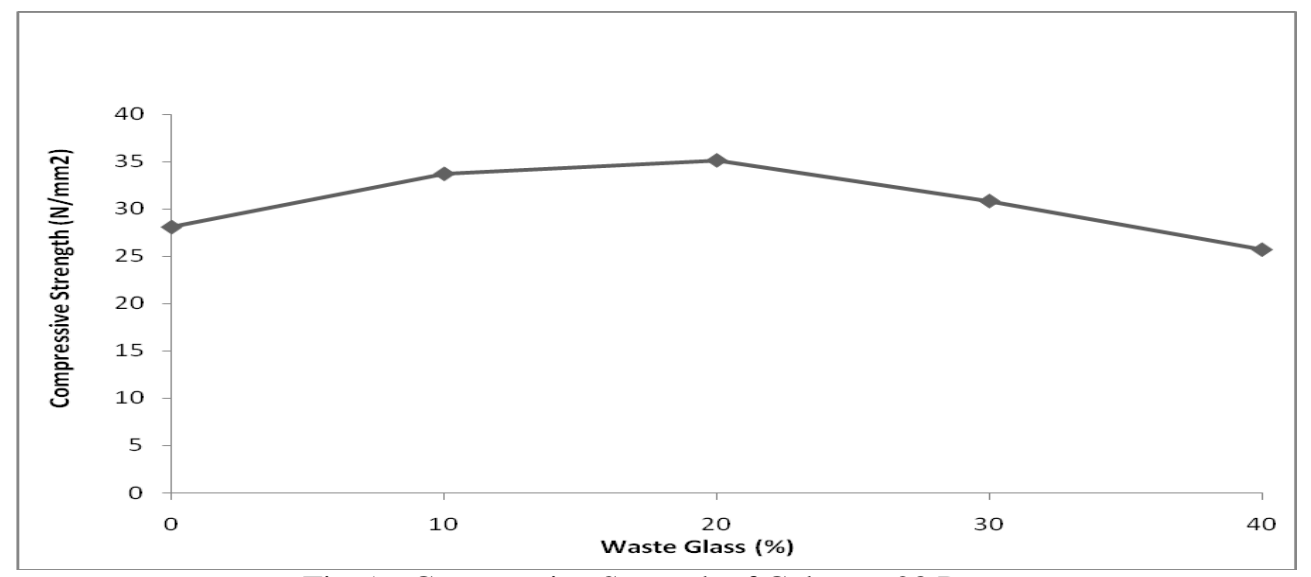

Fig.5 - Compressive Strength of Cubes at 28 Days

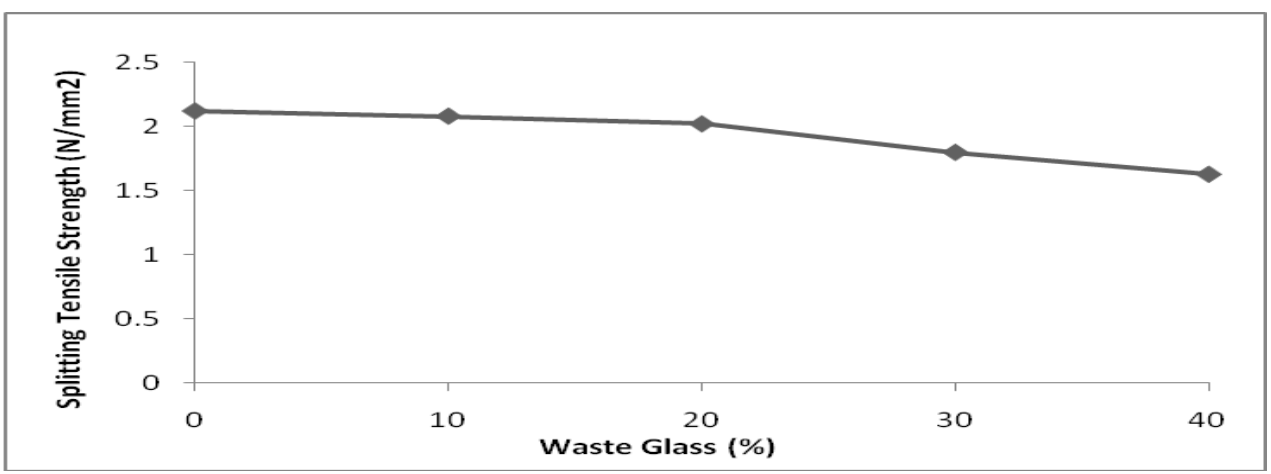

Fig.6 - Split Tensile Strength of Cylinders at 7 Days 


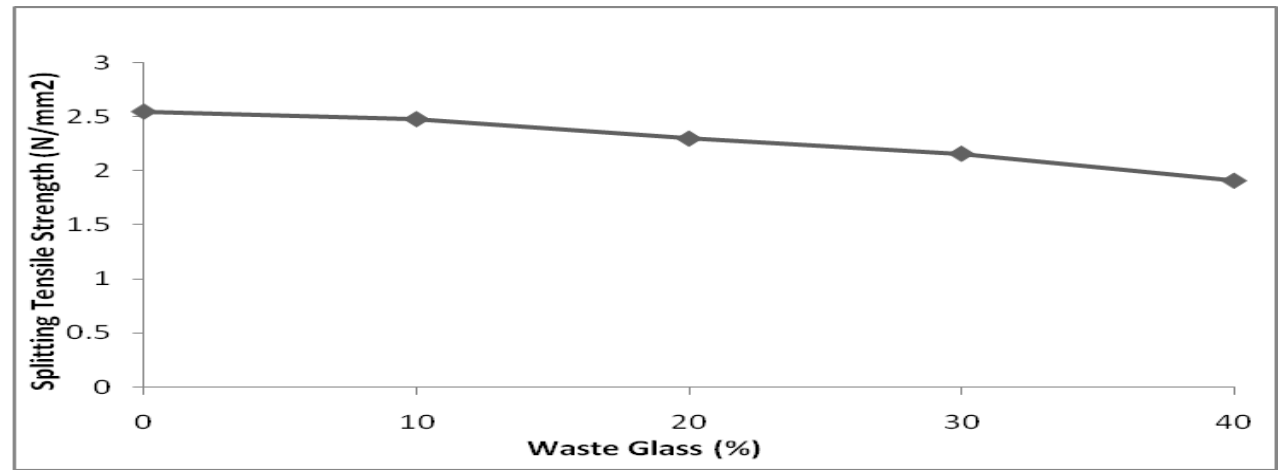

Fig.7 - Split Tensile Strength of Cylinders at 28 Days

TABLE 4 - Water absorption test results for cube specimens of size $150 \mathrm{~mm}$ x $150 \mathrm{~mm}$ x $150 \mathrm{~mm}$

\begin{tabular}{|l|l|l|l|l|}
\hline $\begin{array}{l}\text { Waste glass } \\
\text { content }\end{array}$ & $\begin{array}{l}\text { Average dry weight } \\
\text { before curing }(\mathrm{g})\end{array}$ & $\begin{array}{l}\text { Average wet weight } \\
\text { After 28 days curing }(\mathrm{g})\end{array}$ & $\begin{array}{l}\text { Water } \\
\text { Absorbed }(\mathrm{g})\end{array}$ & $\begin{array}{l}\text { Percentage } \\
\text { WaterAbsorption }(\%)\end{array}$ \\
\hline $0 \%$ & 8382 & 8480 & 98 & 1.169 \\
\hline $10 \%$ & 8343 & 8415 & 72 & 0.863 \\
\hline $20 \%$ & 8235 & 8295 & 60 & 0.729 \\
\hline $30 \%$ & 8130 & 8181 & 51 & 0.627 \\
\hline $40 \%$ & 7952 & 7993 & 41 & 0.516 \\
\hline
\end{tabular}

Table 5 - Light weight test results for cube specimens of size $150 \mathrm{~mm}$ x $150 \mathrm{~mm}$ x $150 \mathrm{~mm}$.

\begin{tabular}{|l|l|l|l|}
\hline $\begin{array}{l}\text { Waste glass } \\
\text { Content }\end{array}$ & $\begin{array}{l}\text { Average dry } \\
\text { weight of cubes }(\mathrm{g})\end{array}$ & $\begin{array}{l}\text { Dry density } \\
\left.(\mathrm{KN} \mathrm{m})^{3}\right)\end{array}$ & $\begin{array}{l}\text { Percentage change in weight with } \\
\text { respect to reference M25 cubes }\end{array}$ \\
\hline $0 \%$ & 8382 & 24.83 & $0 \%$ \\
\hline $10 \%$ & 8343 & 24.72 & $-0.456 \%$ \\
\hline $20 \%$ & 8235 & 24.40 & $-1.753 \%$ \\
\hline $30 \%$ & 8130 & 24.10 & $-3.006 \%$ \\
\hline $40 \%$ & 7952 & 23.56 & $-5.130 \%$ \\
\hline
\end{tabular}

\section{CONCLUSION}

On the basis of results obtained, following conclusions can be drawn:

1. $20 \%$ replacement of fine aggregates by waste glass showed $15 \%$ increase in compressive strength at 7 days and $25 \%$ increase in compressive strength at 28 days.

2. Fine aggregates can be replaced by waste glass up to $30 \%$ by weight showing $9.8 \%$ increase in compressive strength at 28 days.

3. With increase in waste glass content, percentage water absorption decreases.

4. With increase in waste glass content, average weight decreases by $5 \%$ for mixture with $40 \%$ waste glass content thus making waste glass concrete light weight.

5. Workability of concrete mix increases with increase in waste glass content.

6. Splitting tensile strength decreases with increase in waste glass content.

7. Use of waste glass in concrete can prove to be economical as it is non useful waste and free of cost.

8. Use of waste glass in concrete will eradicate the disposal problem of waste glass and prove to be environment friendly thus paving way for greener concrete.

9. Use of waste glass in concrete will preserve natural resources particularly river sand and thus make concrete construction industry sustainable.

\section{ACKNOWLEDGEMENTS}

The authors are thankful to Dr. J. A. Naqash, Associate Professor, Department of Civil Engineering, National Institute of Technology, Srinagar, J\&K, India and Er. M. Iqbal Mirza, Assistant Professor, Department of Civil Engineering, Islamic University of Science and Technology, Awantipora, J\&K, India. 


\section{REFERENCES}

[1]. Asoka Pappu, Mohini Saxena, and Shyan R. Asolekar, "Solid Waste Generation In India And Their Recycling Potential In Building Materials", Regional Research Institute (CSIR) and IIT Bombay, India.

[2]. P Turgut and E.S. Yahlizade, "Research into Concrete Blocks with Waste Glass", International Journal of Civil and Environmental Engineering 1:4 2009.

[3]. Carpenter, A. J. and Cramer, C.M, "Mitigation of ASR in pavement patch concrete that incorporates highly reactive fine aggregate", Transportation Research Record 1668, Paper No. 99-1087,pp. 6067,1999 .

[4]. I. B. Topcu and M. Canbaz, "Properties of Concrete containing waste glass", Cement and Concrete Research, vol. 34, pp. 267-274, Feb. 2004.

[5]. A S Rossomagina, D V Saulin, and I S Puzanov, "Prevention of Alkali-Silica Reaction in Glass Aggregate Concrete", pp-2, Perm State Technical University, Russia.

[6]. V. Corinaldesi, G. Gnappi, G. Moriconi, and A. Montenero, "Reuse of ground waste glass as aggregate for mortars", Waste Management, vol.2, pp.197-201, Jan.2005.

[7]. A. Shayan and A. Xu, "Value added utilization of waste glass in concrete", Cement and Concrete Research, vol-34, pp.81-89, Jan.2004.

[8]. 43 Grade Ordinary Portland Cement - Specification. IS 8112:1989, Bureau of Indian Standards, New Delhi.

[9]. Specification for Coarse and Fine Aggregates from Natural Sources for Concrete. IS: 383-1970, Bureau of Indian Standards, New Delhi.

[10]. Recommended Guidelines for Concrete Mix Design. IS: 10262-1982, Bureau of Indian Standards, New Delhi.

[11]. Methods of Sampling and Analysis of Concrete. IS: 1199-1959, Bureau of Indian Standards, New Delhi.

[12]. Methods of Tests for Strength of Concrete. IS: 516-1959, Bureau of Indian Standards, New Delhi.

[13]. Methods of Tests for Strength of Concrete. IS: 516-1959, Bureau of Indian Standards, New Delhi. 